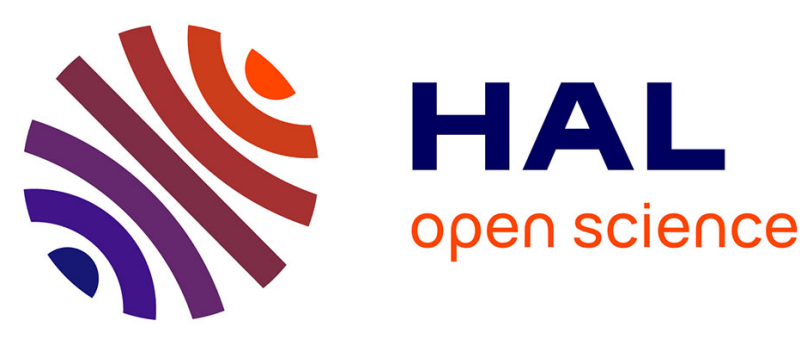

\title{
Glottal Sounds in Korebaju
}

Jenifer Vega Rodriguez, Nathalie Vallée

\section{To cite this version:}

Jenifer Vega Rodriguez, Nathalie Vallée. Glottal Sounds in Korebaju. Interspeech 2021 - 22nd Annual Conference of the International Speech Communication Association, Aug 2021, Brno, Czech Republic. pp.1011-1014, 10.21437/Interspeech.2021-1417 . hal-03337770

\section{HAL Id: hal-03337770 https://hal.science/hal-03337770}

Submitted on 8 Sep 2021

HAL is a multi-disciplinary open access archive for the deposit and dissemination of scientific research documents, whether they are published or not. The documents may come from teaching and research institutions in France or abroad, or from public or private research centers.
L'archive ouverte pluridisciplinaire HAL, est destinée au dépôt et à la diffusion de documents scientifiques de niveau recherche, publiés ou non, émanant des établissements d'enseignement et de recherche français ou étrangers, des laboratoires publics ou privés. 


\title{
Glottal Sounds in Korebaju
}

\author{
Jenifer Vega Rodriguez, Nathalie Vallée \\ Univ. Grenoble Alpes, CNRS, Grenoble INP, GIPSA-lab, 38000 Grenoble, France \\ jenifer-andrea.vega-rodriguez@grenoble-inp.fr, \\ nathalie.valleelgipsa-lab.grenoble-inp.fr
}

\begin{abstract}
Korebaju (ISO639-3: coe) [́kòrèßàhí] is a tonal language spoken in the foothills of the Colombian Amazon. Three field surveys carried out between 2017 and 2019 with six native speakers ( 3 females and 3 males) from the same village provide a set of glottal productions at both phonetic and phonological levels. This study focuses on the four types of glottal units we have found in this language: A set of vowels $/ \mathrm{a}^{2} /, / \mathrm{e}^{\mathrm{r}} /, / \mathrm{o}^{\mathrm{\gamma}} /$, [i?] and [i? $\left.{ }^{3}\right]$ including 3 phonemes; the glottal stop [?] and the consonant [*] transcribed and described as a creaky voiced glottal approximant by [1]. Both consonants occurred in intervocalic contexts and can be analyzed as a suprasegmental feature [constricted glottis] which marks the syllable onset. Finally, we have also found a clear and systematic burst which accompanies the release of the nasal consonants $\left[\mathrm{m}^{2}, \mathrm{n}^{2}, \mathrm{n}^{2}\right]$. No change was found in the EGG signal for these consonants suggesting an abrupt release of the aeroacoustic pressure.
\end{abstract}

Index Terms: Glottal sounds, acoustic phonetics, language description, Korebaju

\section{Introduction}

Korebaju is a Western Tukanoan language spoken in the foothills of the Colombian Amazon. This language is spoken by approximately 2,000 people, distributed into 27 Amerindian reserves, and divided into 18 different villages [2]. Korebaju has four dialectal variations as a result of the union of four indigenous communities (Korebaju, Makaguaje, Tama and Carijona). Three of them lost their language acquiring Korebaju as their primary language. This study focuses on Korebaju's dialectal variation. Korebaju has an inventory of 6 oral vowels

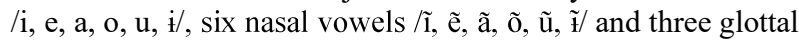
vowels $/ \mathrm{a}^{\mathrm{q}} /, / \mathrm{e}^{\mathrm{p}} /$ and $/ \mathrm{o}^{\mathrm{P}} /$, as well as 17 consonants $/ \mathrm{p}, \mathrm{t}, \mathrm{k}, \mathrm{p}^{\mathrm{h}}, \mathrm{t}^{\mathrm{h}}$, $\mathrm{k}^{\mathrm{h}}, \beta, \phi, \mathrm{s}, \mathrm{h}, \mathrm{w}, \widehat{\mathrm{t}} \mathrm{s}, \mathrm{m}, \mathrm{n}, \mathrm{n}, \mathrm{h} \mathrm{h}, \mathrm{r} /[3]$.

Previous studies on Korebaju refer to glottalization in three different manners. As a phonemic glottal stop / $/$ / occurring in syllable coda position [4]; as a suprasegment that represents either an onset or a compensation of a long vowel elision [5]; and as a phonological process that produces a vowel lengthening when it disappears. This phenomenon is more frequently produced by female than by male speakers [6]. Another description of Korebaju does not present information about glottal sounds [7].

Three different analyses about glottalization have been done in other Tukanoan languages. An analysis for Tukano, an Eastern Tukanoan language, has proposed that glottalization is part of the vowel [8] and plays a contrastive role at the phonemic level. However, the author did not provide a phonetic description of these glottal vowels. Other studies have suggested that the glottal stop [?] is a phoneme in languages such as Piratapuyo [9], Desano [10], Secoya [11], Siona [12] and that it occurs either in coda or onset of syllables.
However, these studies also did not provide a phonetic description of the glottal stop. Finally, an autosegmental analysis has been made for some Eastern Tukanoan languages such as Wanano, Piratapuyo, Tukano, Desano and Siriano [13]. In this analysis, glottalization is represented by a suprasegmental feature [constricted glottis] which is present only in radical morphemes after a vowel carrying a low tone, except for Wanano in which this suprasegment may appear in $\mathrm{H} / \mathrm{HL}$ contexts. According to an association process, [constricted glottis] can be found either in coda in CVCV roots or in CVV onset.

The aim of this study is to clarify the phonological status of glottal sounds in Korebaju, as well as to identify and describe their allophones and functions by considering the general theory of the different glottal mechanisms [1], [14], [15], [16]. We present a detailed phonetic and phonological analysis by examining synchronized audio and EGG signals. The results are discussed in the context of previous analyses done on Korebaju and on the rest of the Tukanoan languages.

\section{Method}

\subsection{Participants}

Six native speakers ( 3 females and 3 males) were involved in the study. All the participants are native speakers of Korebaju and are of Korebaju descent. They also speak Spanish as a second language. Considering the fact that recent social evolution can have an impact on Korebaju, two generations were chosen for this experiment. A first-generation between 23 and 29 years old $(23,25,29)$ and a second between 47 and 56 years old $(47,57,59)$. No speaker had left the community for more than two weeks at the time the recording took place.

\subsection{Materials}

A Zoom H6 recorder was used for the surveys, along with a Shure WH30XLR cardioid headband microphone was placed at a distance of approximately two-finger width from the speaker's mouth in synchronization with an EG2-PC Electroglottograph. Both units were connected to a Motu UltraLite Mk3 Hybrid sound card. Two solar panels belonging to the Korebaju community were used as a power source. Recordings were made in an enclosed area and at certain times to avoid background noise and atmospheric sounds of the Amazon rainforest, such as bird songs and other sounds produced by forest animals.

\subsection{Procedure and data Analysis}

A list of 275 words in a carrier sentence were recorded. The construction of this list made it possible to be systematic in the identification of minimal and quasi-minimal pairs in all 
possible contexts among the six speakers. The phrases were constructed as follow:

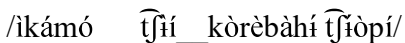

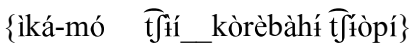

$$
\begin{aligned}
& \text { say-F.SG I _ Korebaju language } \\
& \text { 'I say in Korebaju' }
\end{aligned}
$$

A difference at the level of the sex morpheme ( $\{-\mathrm{mo}\}$ 'F.SG' for female and $\{-\mathrm{mĩ}\}$ 'M.SG' for male) has been found during the production of this sentence. This morpheme is attached to the verbal root and therefore does not affect the production context of the keyword.

Audacity software was used during the audio and EGG recordings. A data quality check was carried out in the field using the Praat software. Praat and Winpitch were used for data analysis. Sound Forge software was used to cut out each word. The different figures of the acoustic signal, EGG and spectrogram were extracted using the Praatfig script [17].

\section{Results and Discussion}

\subsection{Glottal Vowels}

\subsubsection{The non-high vowels / $a^{\text {? }}, e^{\text {? }}, o^{\text {? }}$}

A previous study [3] found a contrast between a set of 3 nonhigh modal vowels /a, e, o/ and their corresponding glottal vowel $/ \mathrm{a}^{2}, \mathrm{e}^{\mathrm{r}}, \mathrm{o} \%$. The present investigation extends this finding and shows that the glottal vowels occur in the first and second position of word roots $\left(\mathrm{C}_{1} \mathrm{~V}^{2}{ }_{1}\right.$ and $\left.\mathrm{C}_{2} \mathrm{~V}^{2}{ }_{2}\right)$, and in some suffixes, that is illustrated in the following minimal pair (a), quasiminimal pair (b) and some affixes (c, d):

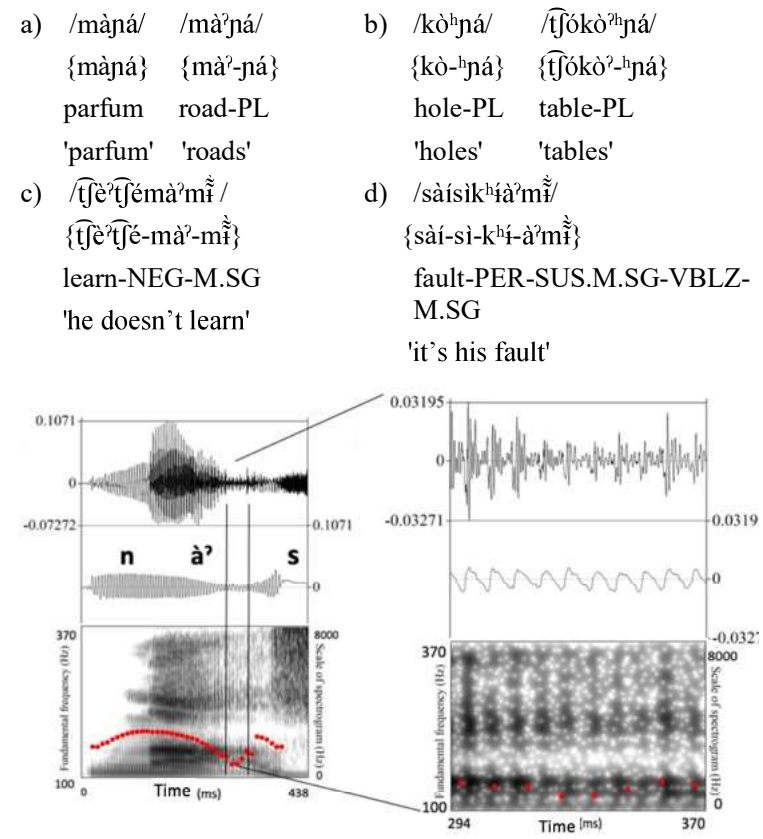

Figure 1: Synchronized speech signal (top), spectrogram with Fo curve (bottom) and EEG signal (mid) of the syllable nà? of the word 'shrimp' [nà'só] with a zoom in the glottalized part.

The spectral analyses of the vowels $\left[\mathrm{a}^{2}\right],\left[\mathrm{e}^{?}\right]$ and $\left[\mathrm{o}^{?}\right]$ show a clear glottal constriction at the end of the voiced part. In most cases, these vowels carry a low tone. According to [3], the duration of glottal and modal vowels is equitable. Figure 1 shows a clear decrease in the amplitude of the acoustic and EGG signals. The EGG signal and the spectrogram show that it is not a creaky voice or a laryngealization, but rather a glottal constriction in the final part of the vowel and it sound is similar to a glottal stop [?].

\subsubsection{The high oral and nasal vowels}

Non-contrastive glottalization has been found in high oral and

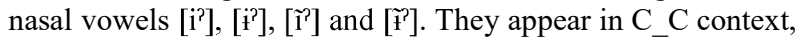
with a condition that the consonant which follows the vowel is an unvoiced stop. These productions are not systematic among speakers. Inter and intra-speakers' variations are attested for these types of productions, regardless of their age, gender, vowel type or pitch contour. However, they occur only in the first syllable $\mathrm{V}_{1}^{\text {? }}$ of word roots. We did not find minimal or quasi-minimal pairs that can support their phonemic status.
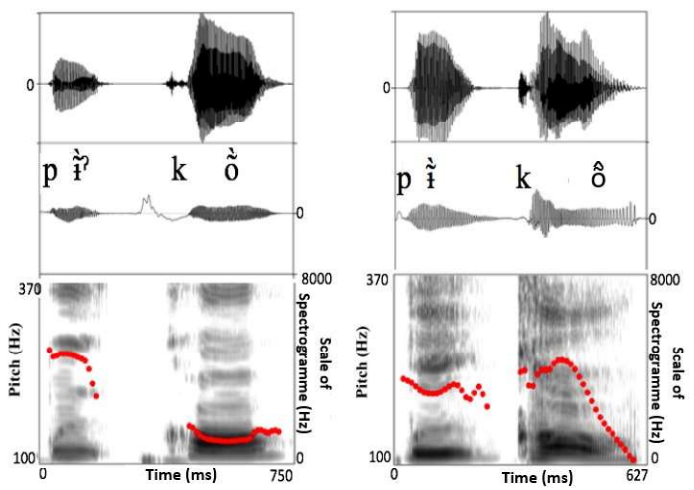

Figure 2: Productions of the word 'aunt' [p ìे $k^{h}$ oे̀] by a female speaker (left), and [p $\left.\hat{v}^{k} h^{\hat{o}}\right]$ by a male speaker (right).

Figure 2 indicates different $\mathrm{V}_{1}{ }^{2}$ voice termination times between two speakers. There is a stop of oscillation in the EGG signal, accompanied by the interruption of $\mathrm{F}_{0}$ for the female's production whereas a gradual decrease is observed for the male production in both EGG signal and wave amplitude. This finding is supported by the voice bar region on the spectrogram which indicates a longer voice termination time.

\subsection{Sounds [*] and [?]}

The sound [*], transcribed and described as a creaky voiced glottal approximant [1] and the glottal stop [?] were found in intervocalic contexts V_V. These productions occur randomly among speakers regardless of age or gender. Their purpose being to mark a syllable onset and to fill an empty onset. These sounds can also appear between morphemes.

However we failed to find contrastive contexts for these sounds. According to previous studies done on Wanano, an other Tukanoan language [13], they are considered to be realized with a "constricted glottis", which is a suprasegmental feature that aims to mark a syllable onset. In Korebaju, these productions are found in root and affixed morphemes, and this finding is different from what has been observed in Wanano language in which this sounds is only part of the radical morphemes. The glottal production is usually (but not all the times) preceded by a low tone (L) followed by a high tone (H). It should be noted that glottal production is not present in all words of the CVV syllable type, as shown in the following examples.
e) [à́t
f) [píá]
/ài/
/píál
'heart'
'chilli'
g) [tóàpí]
/tóàpí/
'leg' 

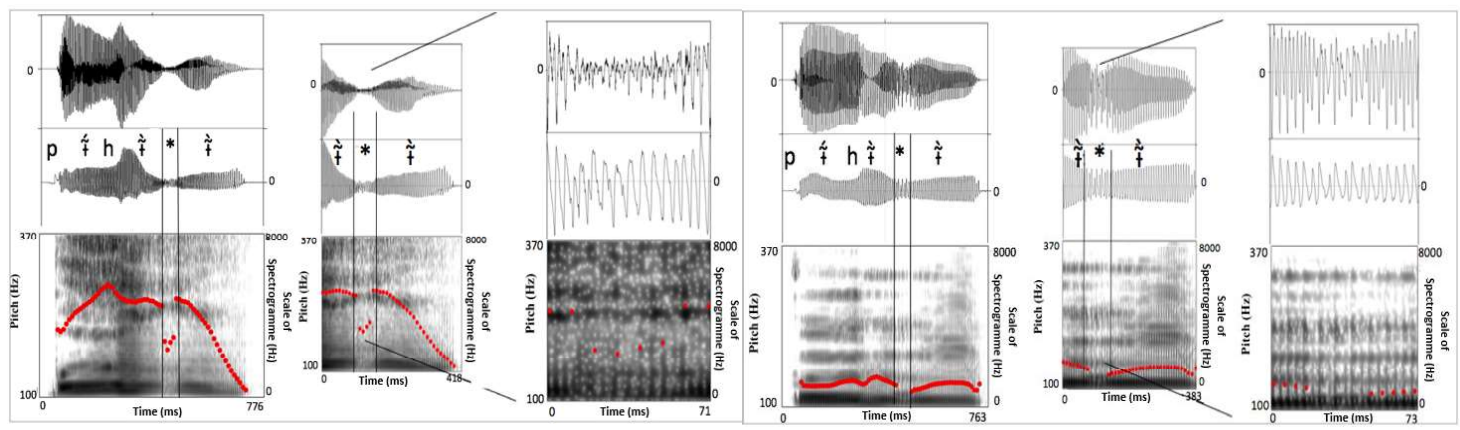

Figure 3: Zooming in on the sound [*] of the word 'sit down' [pû́hi*i] produced by Males 1 (left) and 2 (right).

Productions of sound [*] are variable as illustrated in Figure 3 which present two different productions of this segment. Similar patterns of time evolution and wave irregularity for both signals (audio and EGG) were observed, however, a slight decrease in the amplitudes of the acoustic and EGG waves is observed for Male 1, compared to those of Male 2.

These productions seem to be not contrastive in the language. The creaky voiced glottal approximant [*] is characterized by irregularities of glottal time intervals as well as by the lowering of the amplitude of these intervals in the acoustic and EGG signals. The glottal stop [?] is characterized by a total closure of the glottis, producing an interruption of $\mathrm{F}_{0}$. Contrary to analyses for Gimi [1], no contrast was found between the glottal stop [?] and the creaky voiced glottal approximant [*] in Korebaju. Both glottal productions can occur randomly between speakers (see examples Table 1). This study did not find a specific pattern for the production or choice of these two sounds among Korebaju speakers.

Table 1: Transcription of words (guided by the reading of spectrograms) of three out of six Korebaju speakers.

\begin{tabular}{|c|c|c|c|}
\hline Word & Female 1 & Female 2 & Male 1 \\
\hline He's dressed & [hù?ím解 & [hù*immĩ $]$ & [hù?ímĩ̃̃ \\
\hline Cecropia peltata & [hú?èpít] & [hú*èpí] & [hú*èpí] \\
\hline Oil & [útfàpè?é] & [útfàpè*é] & [útfàpè*é] \\
\hline Road & [mà?á] & [mà?á] & [mà?á] \\
\hline $\mathrm{He}$ & [hà?f́] & [hà Pít & [hàrít] \\
\hline
\end{tabular}

\subsection{Nasal Consonants $\left[m^{2}\right],\left[n^{2}\right]$ and $\left[n^{2}\right]$}

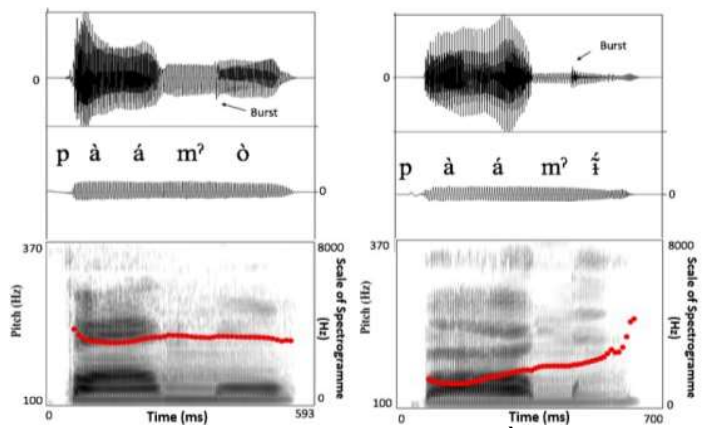

Figure 4: Productions of the word 'no' ì pàám?o] by a female (left) and ì pàám ì̀े by a male (right) speakers.
This study documents the realization of nasal consonants with final explosion (burst) $\left[\mathrm{m}^{2}\right],\left[\mathrm{n}^{2}\right]$ and $\left[\mathrm{n}^{2}\right]$. These realizations were found in many contexts (word initial and intervocalic position, preceded and followed by oral, nasal and glottal vowels). Figure 5 shows a systematic production in the masculine singular morpheme $\{-\mathrm{m} \tilde{\tilde{\mathrm{F}}}\}$ and the feminine singular morpheme $\{$-mò $\}$

This noise burst is not part of a canonical production of the nasal consonants which are characterized by a progressive increase in amplitude of the signal to reach the beginning of the vowel that follows it without any explosion.
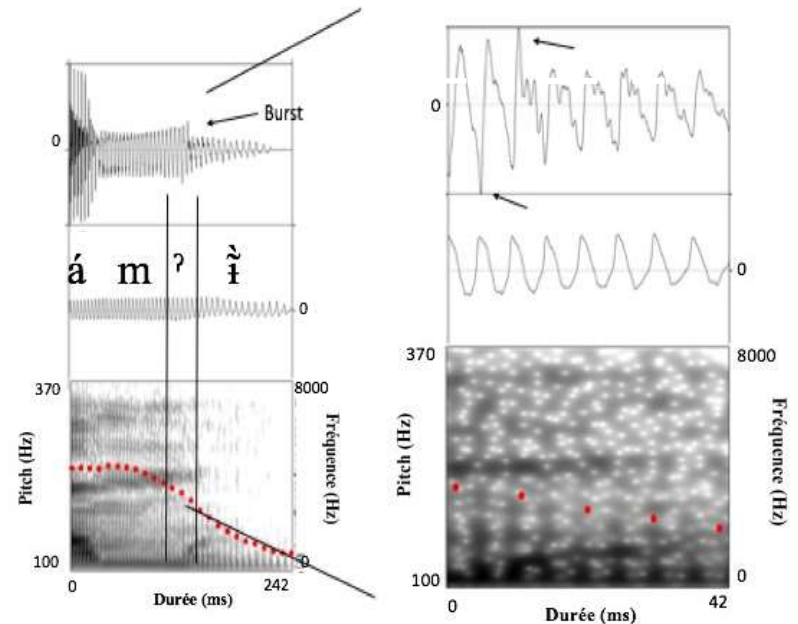

Figure 5: Zooming in on the syllable [mì̀t] of the word [pàám 'خ்̃]' 'no' produced by a male speaker.

Acoustic analysis show that the burst at the end of the nasal consonant is not due to a glottal constriction since the EGG signal is continuous with no change (Figure 5). We hypothesize that the source of this explosion is a glottalic egressive airstream produced by a rise of the larynx creating a rapid release of the oral closure and an abrupt release of the aeroacoustical pressure. However, in this case, it would have been expected that the rise of the intraoral pressure contributes to push the velum upward and helps it to rise to close the velopharyngeal port [18]. Unfortunately, this study does not test this hypothesis. As shown Figure 4 and as said above, a nasal vowel can follows a glottal nasal consonant. A more precise analysis of articulatory phonetics would make it possible to know more about the source of this explosion. 

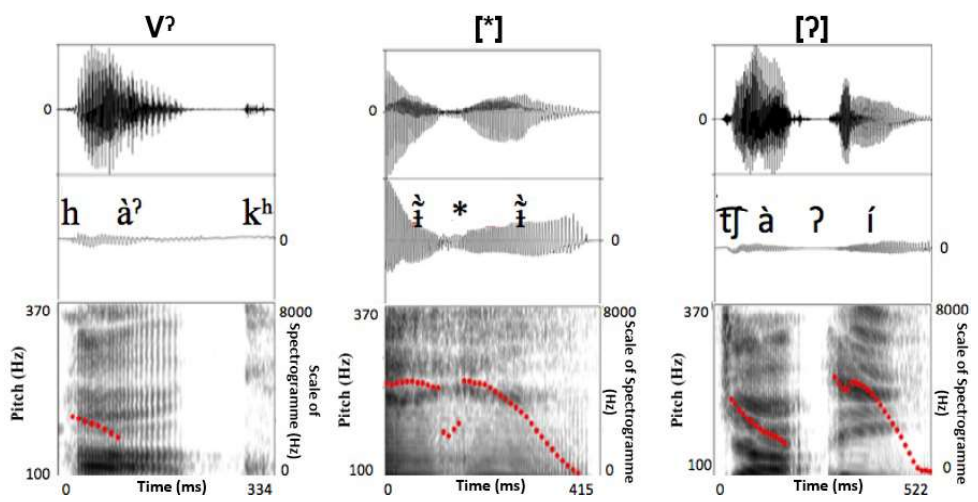

Figure 6: Productions of sounds [a'] in the word 'mother' [hà' $k^{h} o$ ' (left), [*] in the word 'sit down' [pî́hìt the word 'liana yaré' [ิtầ?í] (right) produced by a Korebaju male speaker.

\section{Conclusion}

Figure 6 brings together the three glottal segments encountered in this study [V?], [*] and [?]. In these productions, the vowel $\left[\mathrm{a}^{2}\right]$ exhibits a clear glottal constriction at the second half of its total duration. Indeed, we observed that the second parts of the glottal vowels are characterized by irregular oscillations of the acoustic wave and interruption of the EGG signal. The glottal stop [?], in intervocalic context (e.g. [ [tà?í] 'liane yaré'), presents an interruption of the audio and EGG signals. Finally, the production of the creaky voiced glottal approximant $[*]$, for example in this intervocalic context, displays a reduction in intensity of the EGG signal as well as of the acoustic signal, and a decrease of $F_{0}$. Our finding refutes the phonemic status of the glottal stop [?] in Korebaju, contrary to previous analysis [4]. The lack of contrast between words with and without this glottal stop, as well as its distribution restricted to intervocalic contexts, cannot allow us to define this segment as a phoneme of Korebaju. This study did not find any generational or gender differences in the analyzed productions.

By referring to [16] and by following the analysis in Wanano, we suggest that this production is probably a suprasegmental feature that marks a syllable onset. The glottal appendix found at the end of nasal consonants and presented at the beginning of this paper as a part of nasal glottal $\left[\mathrm{m}^{2}\right],\left[\mathrm{n}^{2}\right]$ and $\left[n^{2}\right]$ has been refuted. These productions have continuous and rather stable resonance frequencies without laryngealization other their total duration and present a short and intense burst in the low frequencies in the very last instants of the consonant. This explosion is not part of a canonical production of the nasal consonants, which are characterized by a progressive increase in signal amplitude to reach the beginning of the vowel that follows it without any burst. In Korebaju, an increase of the amplitude is also observed throughout the duration of the consonant until the final burst.

Other investigations are underway to complete the corpus and to make quantitative measurements to better understand both phonemic status and phonetic nature of the glottal sounds in Korebaju and their link with the segmental and suprasegmental levels.

\section{References}

[1] P. Ladefoged. and I. Maddieson, The sounds of the world's languages. Oxford: Blackwell Publishers, 1996.
[2] Korebaju community, Proposal of Korebaju's pedagogical model. Caqueta, Colombia, 2011.

[3] J. Vega Rodriguez "The Vowel System of Korebaju" in INTERSPEECH 2019 - $20^{\text {th }}$ Annual Conference of the International Speech Communication Association, September 1519, Graz, Austria, Proceedings, 2019, pp. 3975-3979.

[4] D. Cook. and L. Criswell, El idioma Koreguaje (Tukano Occidental). SIL. Lomalinda: Editorial Townsend, 2013.

[5] C. Dupont, La Langue Koreguaje (Tukano Occidental). Phonologie et Morphologie, Unpublished Manuscript.

[6] M.D. Cristancho Botia, and N.B. García Moreno, Aspectos Fonológicos De La Lengua Coreguaje. Undergraduate thesis. Universidad Nacional de Colombia, Bogotá, Colombia, 1982.

[7] G.E. Herrera Casimilas, Manual de pronunciación española para hablantes koreguajes basado en el análisis contrastivo a nivel fonológico de los dos idiomas. Undergraduate thesis. Universidad Nacional de Colombia, Bogotá, Colombia, 1990.

[8] A.P. Sorensen, The Morphology of Tukano. PhD dissertation. University of Columbia, 1969.

[9] J. Klumpp, and D. Klumpp, "Sistema Fonológico del Piratapuyo". Sistemas Fonológicos de Idiomas Colombianos V, pp. 107-20, 1973.

[10] M. Miller, "Desano Grammar". Studies in the languages of Colombia, 6. Dallas/ Arlington: Summer Institute of Linguistics and the University of Texas at Arlington, 1999.

[11] R. Vallejos, "El secoya del Putumayo: aportes fonológicos para la reconstrucción del Proto-Tucano Occidental". LIAMES : Línguas Indígenas Americanas, Vol. 13(1), 67-100. 2013.

[12] M. Bruil, Clause-typing and evidentiality in Ecuadorian Siona. $\mathrm{PhD}$ dissertation. Universiteit Leiden, Leiden, 2014.

[13] K. Stenzel, "Glottalization and other suprasegmental features in Wanano". International Journal of American Linguistics, Vol. 73, 331-66, 2007.

[14] J.H. Esling and J.G. Harris, "State of the glottis: An articulatory phonetic model based on laryngoscopic observations". In W.J. Hardcastle and J. Beck (Eds.) A figure of Speech: A Festschrift for John Laver (pp. 347-383). Mahwah, NJ: Lawrence Erlbaum Associates, 2005.

[15] J.H. Esling, C. Zeroual and L. Crevier-Buchman, "A study of muscular synergies at the glottal, ventricular and aryepiglottic levels". In Proceedings of the $16^{\text {th }}$ International Congress of Phonetic Sciences, 2007, pp.585 -588. Saarbrücken.

[16] J.A. Edmondson. "The valves of the throat and their functioning in tone, vocal register, and stress: laryngoscopic case studies". Phonology, Vol. 23 (2), 157-191, 2006.

[17] M.C. Nguyen, Script Praatfig, 2017.

[18] N. Vallée, S. Rossato, and I. Rousset. "Favoured syllabic patterns in the world's languages and sensorimotor constraints". In Approaches to phonological complexity. In Pellegrino, F., Chitoran, I., Marsico, E., \& Coupé, C. (Eds.). Walter de Gruyter. Vol. 16. pp. 11-39, 2009. 